Claremont Colleges

Scholarship@ Claremont

Scripps Faculty Publications and Research

Scripps Faculty Scholarship

$1-1-1990$

\title{
Feminist Literary Criticism and the Author
}

Cheryl Walker

Scripps College

\section{Recommended Citation}

Walker, Cheryl. "Feminist Literary Criticism and the Author." Critical Inquiry. 16.3 (1990): 551-571.

This Article is brought to you for free and open access by the Scripps Faculty Scholarship at Scholarship @ Claremont. It has been accepted for inclusion in Scripps Faculty Publications and Research by an authorized administrator of Scholarship @ Claremont. For more information, please contact scholarship@cuc.claremont.edu. 


\section{Feminist Literary Criticism and the Author}

\section{Cheryl Walker}

In the late 1960s French theorists began to take account of the phenomenon we now know familiarly as "the death of the author." Writers like Michel Foucault raised startling questions about the voice or voices in a text, asking, "What difference does it make who is speaking?" In the days of author criticism, the author was thought to be the speaker whose presence behind the text signaled his (or her, though usually his) capacity as originator. Textual interpretations often alluded to this historical personage as a genius whose subjectivity, once understood, provided a set of principles for discovering the underlying unity of a great work of literature.

According to Foucault, in his essay "What Is an Author?" (1969), this authorial presence has disappeared. In the modern period the author is an effacement, an absence of the personal, who writes him- or herself out of the text through the strategies of fictive composition. Nonetheless, we still have what Foucault calls "the author function," which allows us to classify "a Woolf novel," for instance, as a different kind of entity than a novel by Jane Austen. The author-function is not a subjective presence but a signature, in which "the author's name serves to characterize a certain mode of being of discourse" ("WIA," p. 107).

For advice on this essay, 1 wish to thank Frances McConnel, John Peavoy, Elizabeth Minnich, and Marilyn Edelstein. I also owe a debt of gratitude to Walter Benn Michaels, who started me down this path by forcing me to rethink my own naive assumptions about authors.

1. Michel Foucault, "What Is an Author?" trans. Josué V. Harari, in The Foucault Reader, ed. Paul Rabinow (New York, 1984), p. 120; hereafter abbreviated "WIA."

Critical Inquiny 16 (Spring 1990)

1990 by The University of Chicago. 0093-1896/90/1603-0011\$01.00. All rights reserved. 
Though the death of the author may be variously traced to certain nineteenth-century writers like Stéphane Mallarmé and Friedrich Nietzsche, today some of us associate it more often with the theoretical moves of French critics like Foucault, Roland Barthes, or Jacques Derrida who have questioned the whole notion of the unified subject, the center, the self. ${ }^{2}$ Individuals cannot be authors, in part, because there is no such center or integrated core from which one can say a piece of literature issues. The binary oppositions between self and other, inside and outside, are two of the many dualities Derrida has powerfully deconstructed. The self is a structuring mechanism, not a godlike creator. Unlike the deity, we do not originate; we only translate among various given languages of feeling: "the writer can only imitate a gesture that is always anterior, never original. His only power is to mix writings, to counter the ones with the others, in such a way as never to rest on any one of them," Barthes says ("DA," p. 146).

In 1969 Foucault is less extreme than Barthes or Derrida in the sense that he believes "it would be pure romanticism . . . to imagine a culture in which the fictive would operate in an absolutely free state, in which fiction would be put at the disposal of everyone and would develop without passing through something like a necessary or constraining figure" ("WIA," p. 119). Thus he does not at that time propose that texts be construed as fields of discourse without any boundaries (authorial or otherwise) to limit the free play of the signifier, as Barthes and Derrida do. Instead, he diverts our attention from the intentions of the text to "the modes of circulation, valorization, attribution, and appropriation of discourses" ("WIA," p. 117) or, in other words, to the reception of texts according to the modes of distribution established by power relations. However, he also considers significant "the subject's [the author's?] points of insertion, modes of functioning, and system of

2. See Roland Barthes, "The Death of the Author," Image, Music, Text, trans. Stephen Heath (New York, 1977), pp. 142-48; hereafter abbreviated "DA." For Jacques Derrida's conception of the role of the subject, see his Of Grammatology, trans. Gayatri Chakravorty Spivak (Baltimore, 1976); "Structure, Sign and Play in the Discourse of the Human Sciences," trans. Alan Bass, in Critical Theory Since 1965, ed. Hazard Adams and Leroy Searle (Tallahassee, Fla., 1986), pp. 83-94; and Limited Inc (Evanston, Ill., 1988).

Cheryl Walker is professor of English and humanities at Scripps College. She is the author of The Nightingale's Burden: Women Poets and American Culture before 1900 (1982) and Masks Outrageous and Austere: Culture, Psyche, and Persona in Modern Women Poets (forthcoming). She is currently editing an anthology of nineteenth-century women poets and a book of essays about feminist criticism in the wake of post-structuralism. 
dependencies" within culture (“WIA,” p. 118), a point to which I will return later.

The issues that Foucault raises about reception and reading are certainly part of the contemporary discussion of literature. However, they are not the only issues with which we, as today's readers, are concerned. Discussions about the role of the author persist and so we continue to have recourse to the notion of authorship.

For instance, in her recent book Sexual/Textual Politics (1985), the feminist critic Toril Moi feels called on to return to these twenty-yearold issues in French theory to tell us what it has meant to speak of the author, when she says: "For the patriarchal critic, the author is the source, origin and meaning of the text. If we are to undo this patriarchal practice of authority, we must take one further step and proclaim with Roland Barthes the death of the author."

In the course of this essay I wish to reopen the (never fully closed) question of whether it is advisable to speak of the author, or of what Foucault calls "the author function," when querying a text, and I wish to reopen it precisely at the site where feminist criticism and post-structuralism are presently engaged in dialogue. Here in particular we might expect that reasons for rejecting author erasure would appear. However, theoretically informed feminist critics have recently found themselves tempted to agree with Barthes, Foucault, and the Edward Said of Beginnings that the authorial presence is best set aside in order to liberate the text for multiple uses. ${ }^{4}$

I wish to examine the ways in which feminist critics have moved away from what some would call the old-fashioned assumption that what we do when we read is try to decipher the intentions of the text in terms of what we assume to be the author's deepest self. I also wish to make a further argument for reanimating the author, preserving author-function not only in terms of reception theory, as Foucault would seem at one point to advocate, but also in terms of a politics of author recognition.

\section{1}

A mild form of author questioning can be found in two recent anthologies of feminist theory. In their 1985 Making a Difference: Feminist Literary Criticism, Gayle Greene and Coppélia Kahn advise feminist critics to pay attention to those theorists who "in liberating the text 'from the authority of a presence behind it,' released it 'from the

3. Toril Moi, Sexual/Textual Politics: Feminist Literary Theory (London and New York, 1985), pp. 62-63; hereafter abbreviated STP.

4. See Edward W. Said, Beginnings: Intention and Method (New York, 1975), p. 162. 
constraints of a single and univocal reading,' making it 'available for production, plural, contradictory, capable of change . . . unfixed, a process." 5

Though the postmodern feminist critic is almost certain to practice her trade in defiance of authority, often proceeding polyvocally herself and rarely claiming that a unified, coherent, and transcendental subjectivity lies behind the text, nevertheless the author has never quite disappeared from our practice. The above quotation from Greene and Kahn, for instance, is less doctrinaire than Barthes, suggesting not that we refuse all attempts at deciphering a text's meaning but that a single referent be replaced by an interactive model of the text as inviting interpretation through a process of multiple readings and references.

This quotation itself is drawn from a double authorship where we do not know which of the two voices (Greene's or Kahn's) is speaking in any given phrase. Furthermore, there is a third presence (or absence) in the interpolated quotations from Catherine Belsey, who is herself quoting Derrida. Clearly, there are many voices speaking in this text. But the ascription to Belsey suggests as much as anything that we are unwilling to do away with the author entirely, though it should be noted that when Foucault speaks of the author, he does not mean simply the proper name of the writer but a system of limiting meaning that allies the proper name with a whole series of assumptions about what belongs to it. (A "Woolf novel" is not simply one written by Virginia Woolf.) The author's name is not, for Foucault, just a proper name like the rest. Still, Greene and Kahn feel obliged to mention Belsey as the "author" of the quoted remarks. What are the implications of this gesture? Foucault suggests that such an act may be a consequence of bourgeois ideology because it signifies that the text "belongs" to an individual like a piece of private property. My own instincts tell me that Greene and Kahn's attribution may involve the notion that texts function like property, but textual property, they imply, has special attributes: it is alienable and inalienable at the same time. ${ }^{6}$

From one point of view, they are joining with Belsey, thus, in a sense, making a communal statement in which there is no need to divide up authorship like property. From another viewpoint, of course,

5. Gayle Greene and Coppélia Kahn, "Feminist Scholarship and the Social Construction of Woman," in Making a Difference: Feminist Literary Criticism, ed. Greene and Kahn (London and New York, 1985), p. 25; also see pp. 27-28. The interpolated statements are from Catherine Belsey, Critical Practice (London and New York, 1980), pp. 136, 134.

6. Nancy K. Miller disagrees with Foucault about the possibility of finding a language site outside bourgeois ideology. Since she appears to agree with Barthes that no such site exists, she finds appealing certain metaphors of stealing and disguise in order to suggest the need for reforming the dominant text. See Miller, "Changing the Subject: Authorship, Writing, and the Reader," in Feminist Studies / Critical Studies, ed. Teresa de Lauretis (Bloomington, Ind., 1986), pp. 102-20, esp. p. 111 ; hereafter abbreviated "CS." 
proper ascription is necessary in order not to be caught in an act of misappropriation, an act of stealing. However, this politics need not be simply one of guilt (stealing is sinful) nor one of fear (stealing is punishable); it can also be one of respect (we wish you to have the credit for configuring this semantic sequence that we are appropriating for our own purposes). In all three cases, the author remains in some form.

This is not, however, the same thing as suggesting, as Steven Knapp and Walter Benn Michaels have done in their essays "Against Theory" and "Against Theory 2," that the meaning of a text is always and only what its author intends. ${ }^{7}$ It is, to the contrary, a position neither consonant with Barthes's belief that the most revolutionary form of criticism requires refusing to discover the author in a space of writing nor synonymous with the proposition (à la Knapp and Michaels) that the author provides the only locus in which meaning can properly be ascribed. What we are often seeking as feminists, it seems, is a third position.

So far the discussions within feminist criticism concerning the implications of post-structural theory for the positioning of the author have generally proceeded from theory to practice. (There continues to be much practice, of course, in which the theoretical issues are not even raised.) The theorists, however, reasonably wonder: should we valorize the author if such a position necessarily implies the same kind of repression we associate with patriarchy?

It is well to remember Foucault's caution here that the authorfunction implies a convergence of many indicators given status within a particular context. "As a result, we could say that in a civilization like our own there are a certain number of discourses that are endowed with the 'author function,' while others are deprived of it" ("WIA," p. 107). Though Foucault's examples of deprivation concern private letters and contracts that, he says, do not have authors in this sense, we might also remember the way the canon guarantees authorship to certain privileged writers while others are degraded to the level of mere literary names, which only a Trivial Pursuit-minded individual would think it necessary to "know" in the kind of detail that, we are told, a literate person should know, say, Dostoyevski. ${ }^{8}$

7. See Steven Knapp and Walter Benn Michaels, "Against Theory," in Against Theory: Literary Studies and the New Pragmatism, ed. W. J. T. Mitchell (Chicago, 1985), pp. 1 1-30, and Knapp and Michaels, "Against Theory 2: Hermeneutics and Deconstruction," Critical Inquiry 14 (Autumn 1987): 49-68. Knapp and Michaels make a radical argument that a text has only one meaning, the meaning its author intends, and that that meaning never changes. The only point of literary criticism is to figure out what the author intended.

8. Moi's argument is different. Since she believes that author-critics have engaged in an imperialist attempt to repress, undermine, overwhelm, or otherwise colonize the freedom of interpretation, we must get rid of all versions of the author, male or female. 
My second example of recent author discussion concerns Nancy K. Miller's "Changing the Subject: Authorship, Writing, and the Reader." Miller returns to the question of authorship, hoping to keep several balls in the air at the same time: post-structuralism's assault on the author and feminism's productive attention to the writing subjectivities of women. ${ }^{9}$ Miller finds useful for feminism some aspects of the ideology of "the death of the author." She reminds us that "it is, after all, the Author, canonized, anthologized, and institutionalized, who excludes the less-known works of women and minority writers from the canon, and who by his authority justifies the exclusion" ("CS," p. 104). Yet Miller is suspicious of applying the same version of author erasure to women writers since our relation to subjectivity formation has been different.

The postmodernist decision that the Author is dead, and subjective agency along with him, does not necessarily work for women and prematurely forecloses the question of identity for them. Because women have not had the same historical relation of identity to origin, institution, production, that men have had, women have not, I think, (collectively) felt burdened by too much Self, Ego, Cogito, etc. ["CS," p. 106]

Miller leaves open the possibility of retaining a reconceived authorfunction in the case of women writers. However, she does indeed "change the subject" as her title implies by concentrating primarily on women as readers (a position she like Barthes believes to be "the necessary counterpoint to the death of the Author" ["CS," p. 104]). Furthermore, she backs away from post-structuralism as an ontology (perhaps a deontology) that denies meaning to coherent subjectivity and to the author (any author, male or female) as the originator of discourse. Her argument seems to imply that the notion of the death of the author arises because men feel overburdened by ego, self, and so on rather than, as Foucault would have it, that the author is a function created entirely by the writing itself and unlocatable outside of it. Foucault says, "In short, it is a matter of depriving the subject (or its substitute) of its role as originator, and of analyzing the subject as a variable and complex function of discourse" ("WIA," p. 118).

If authors only emerge from the written texts, then the question of how these texts were written in the first place attempts to go "behind"

9. De Lauretis makes an interesting assessment of Miller in her introduction to Feminist Studies/Critical Studies where she says that Miller is a keen observer of the "double temporality of intellectual history, which unfolds concurrently-and discontinuously-in 'women's time' of feminist criticism and in 'the Eastern Standard time' of traditional scholarship" (de Lauretis, "Feminist Studies/Critical Studies: Issues, Terms, and Contexts," in Feminist Studies / Critical Studies, p. 16). 
the writing in a way rendered illegitimate by critics like Barthes, whom Miller seems to wish not to attack. Identity formation may have different structural patterns for women, but these are irrelevant to the question of whether women can, under such post-structural theories of textuality, operate as the authors of their own works. Miller says that we must pay attention to the "asymmetrical demands generated by different writing identities, male and female, or, perhaps more usefully, canonical or hegemonic and noncanonical or marginal" ("CS," p. 105). But this is surely a different perspective than that of Foucault and Barthes, as it implies that women (or noncanonical and marginal writers) can be authors whereas men (or canonical and hegemonic writers) cannot. The question remains, how can an absence generate a demand?

Moi's is probably the most radical feminist borrowing of French male theory in its insistence on a feminist proclamation of the death of the author. Moi's Sexual/Textual Politics has had very wide circulation, and so it seems worthwhile to look more closely now at what she does with this notion in her own work. To begin with, she discounts the tendency in Anglo-American feminist criticism to supply biographical material about an author (in her case, Woolf) when writing about literary texts. Dismissing as "emotionalist" and irrelevant Jane Marcus's notation that Woolf trembled as she wrote, Moi asks: "does it really matter whether or not Woolf was in the habit of trembling at her desk?" (STP, p. 17).

Presumably it doesn't matter, if the author is "dead" as a reference point for the meaning of the text. Yet in terms of some of Moi's other critical assumptions, her position on this issue seems contradictory. When Foucault asked "What difference does it make who is speaking?" he may have been suggesting that we reveal our own epistemological assumptions and our own politics of interpretation by our insistence on a certain notion of subjectivity as speaking. It can never be shown that the treatment of the author as speaking makes no difference, since every way of constructing the text makes some difference. The point is to consider what difference such a difference makes.

Similarly, nothing can be proven irrelevant to a text unless some principles controlling relevance (that is, restricting potential hermeneutic strategies) are posited, a position problematic for those who, like Moi, are committed to radical open-endedness. If the text cannot be closed to effects previously considered extrinsic to it, effects like its reception, the history of its conventions, the sociopolitical context of its composition, and so on, it also cannot be closed to the biographical contexts of its writing.

The second way in which Moi's argument seems to me problematic is in its radical distinction between fictional writing and critical writing. Moi's own textual politics involves an extended dialogue with authors who are critics. These critics operate in terms of the "author function" 
Foucault describes so well. That is, Moi ascribes to these critic/authors certain unified positions that categorize them as speakers. Their works are not read by Moi as indeterminate, contradictory, elusive; she assumes that we can sum them up, know what they are saying, and place them in terms of the way their arguments are made. Information about their sociohistorical relations is important to her classifications. An Anglo-American heritage is different from a French one.

In short, Moi preserves the notion of authorship when reading critics while advising we dispense with it when reading literature, presumably following Foucault's notion that the author-function does not affect all discourses in a uniform and constant way. Though recently we have come to know a good deal more about the biographical circumstances of critics like Sandra Gilbert and Susan Gubar than used to be typical outside the rumor mill of academy insiders, Moi implies we read criticism differently. We don't try to locate autobiographical traces in the work of discursive writers; we simply use the proper names as a shorthand for identifying the theory. We do not concern ourselves with the sociological conditions of composition.

Or do we? Certainly the recent brouhaha over the publications of Paul de Man in the Nazi-oriented journal Le Soir during the early 1940s has spawned a rereading of his critical works by both detractors and sympathizers. In fact, in what seems to be a radical reversal of earlier positions, Derrida has recently recommended such a rereading in order to understand the historical personage Paul de Man. ${ }^{10}$ In Moi's own case, her close association with British Marxist critic Terry Eagleton during the historical moment of Sexual/Textual Politics has led some readers to say privately that the book was either overdetermined by Eagleton's own thinking or, conversely, an extended argument with Eagleton's brand of feminism. My point here is certainly not to make an argument against Moi ad feminam but to question her separation between fictional and critical texts.

It seems to me that the assumptions operating here are deeply problematic even within the context of post-structuralism. It is possible to deconstruct Moi's argument by remembering with it the contemporary presentation of all culture as discourse and Derrida's proposition, in particular, that there is nothing outside the text. The false dichotomy Moi offers is that of assuming only an old-fashioned, authorcentered critical practice based on a unified, coherent, bourgeois notion of self or a contradictory, open-ended, free plane of discourse on which critics range over a space of writing " ceaselessly posit[ing] mean-

10. See Derrida, "Like the Sound of the Sea Deep within a Shell: Paul de Man's War," trans. Peggy Kamuf, Critical Inquiry 14 (Spring 1988): 590-652. The Summer 1989 issue of Critical Inquiry contains responses to this essay. 
ing ceaselessly to evaporate it," as she suggests, using Barthes's words $\left(S T P\right.$, p. 63). ${ }^{11}$ Like the distinctions between critical and creative writing, and those between historical circumstances and literary texts, this dichotomy somehow forgets other propositions that belong to the very forms of critical practice-feminism, post-structuralism-Moi herself claims to be interested in bringing to bear.

As I have tried to suggest above, it is not true that we read criticism and fiction in diametrically opposed ways, limiting the importance of the author's subjectivity in one while exalting it in the other. Furthermore, the reversal of these positions (erasing the author of fictive work while preserving the author of criticism) also seems misguided.

In terms of post-structuralism, it is worth paying attention to the attack made by Hayden White and others on the old division between creative and critical discourse. ${ }^{12}$ White and Dominick LaCapra have both argued that this division will not bear scrutiny. They have been at pains to show that analytical history uses the same rhetorical techniques, the same tropes, the same narrative strategies as literature. Narrative history, narrative criticism, and narrative literature all use the formulae of narrativity.

Presumably Moi would argue that she is not writing narrative criticism. Yet all of the critical texts Moi engages tell a story. In fact, it is precisely because Moi doesn't like the story that Gilbert and Gubar tell that she reminds us that telling a story "can in itself be constructed as an autocratic gesture" (STP, p. 68). Does Moi believe she herself is doing anything else? Is her text not an elegant story about the way female critics, connected to one another like characters in a Woolf novel, engage in gestures of mutual recognition and respect while at the same time seeking to escape the party to find room for solitary reflection and independence? Doesn't her book have a clearly identifiable beginning, middle, and end at which the defiant figure of Julia Kristeva emerges somewhat battered but victorious nonetheless, repeating a pattern with roots as ancient as storytelling itself?

Second, the distinction between history and literature (reanimated where Moi dismisses biographical circumstances in favor of the texts themselves) somehow assumes that the process of juxtaposing historical information with literary artifacts is something other than what some post-structuralists assume it is, an experience of intertextuality to be valued no more and no less than any other intertextual exercise for the illumination, the sparks of recognition, it produces. In his chapter "History and the Novel" in History and Criticism (1985), LaCapra advises

11. See "DA," p. 147.

12. See Hayden White, Metahistory: The Historical Imagination in Nineteenth-Century Europe (Baltimore, 1973). See also Dominick LaCapra, History and Criticism (Ithaca, N.Y., 1985), and his more recent History, Politics, and the Novel (Ithaca, N.Y., 1987). 
historians and literary critics to engage the past through such a process of intertextual dialogue:

A move in a desirable direction is, I think, made when texts are understood as variable uses of language that come to terms withor "inscribe"-contexts in various ways-ways that engage the interpreter as historian and critic in an exchange with the past through a reading of texts.

Contexts of interpretation are at least three-fold; those of writing, reception, and critical reading.

Contexts of writing include the intentions of the author as well as more immediate biographical, sociocultural, and political situations with their ideologies and discourses. They also involve discursive institutions such as traditions and genres. ${ }^{19}$

Like LaCapra's advice to the critic, Derrida's famous statement that there is nothing outside the text implies that we are free to develop intertextual dialogues by juxtaposing biography with literature, history with criticism, medical handbooks with political treatises, and so forth. The life of the author is not a privileged content, since it, too, is a set of texts (Gilbert has called it "the life-text"), but the question remains as to why such texts should be denied or repressed, as they appear in Moi's argument.

Most disturbing for me, however, are what I feel to be the antifeminist implications of Moi's insistence that we joyfully proclaim the death of the author. Miller usefully reminds us that "the removal of the Author has not so much made room for a revision of the concept of authorship as it has, through a variety of rhetorical moves, repressed and inhibited discussion of any writing identity in favor of the (new) monolith of anonymous textuality" (“CS," p. 104). What Miller points to here are the limitations of some applications of post-structuralism in meeting the needs of current feminism. In fact, what we need, instead of a theory of the death of the author, is a new concept of authorship that does not naively assert that the writer is an originating genius, creating aesthetic objects outside of history, but does not diminish the importance of difference and agency in the responses of women writers to historical formations. The loss of the writer runs us the risk of losing many stories important to our history. Radical freedom, of the sort Moi seems to advocate, may in the end leave us without the tools necessary to consider the way biography and fiction are in dialogue with one another and provide a critique of patriarchy as well as, in some cases, models of resistance. Barthes's form of textual response (though not Foucault's) would leave us with no literary history whatsoever.

13. LaCapra, "History and the Novel," History and Criticism, p. 127. 
Here it may be useful to examine briefly the way contemporary feminist critics, more or less theoretical, are using the author-function in literary criticism of the late 1980s. I will take my examples from the field I know best, criticism concerned with women poets. Though my examples are in no way meant to represent all contemporary positions on authorship among feminist critics, they are instructive both in the way one (Paula Bennett) suggests the problems of ignoring the attack on the author and in the way the others (Alicia Ostriker, Jan Montefiore, and Cora Kaplan) adhere to a revised concept of authorship.

Bennett's My Life A Loaded Gun: Female Creativity and Feminist Poetics, Kaplan's Sea Changes: Essays on Culture and Feminism, and Ostriker's Stealing the Language: The Emergence of Women's Poetry in America were all published in 1986. Montefiore's Feminism and Poetry: Language, Experience, Identity in Women's Writing appeared in $1987 .{ }^{14}$ Two of these critics are American (Bennett and Ostriker); the other two write in England (though Kaplan is American by birth). It seems to me roughly true that it is still possible to be an American feminist literary critic without taking into consideration recent French theory; it is less possible to be a British one.

This might in part explain the almost total exclusion of French theory from Bennett's book. (There is one footnote listing several sources on French feminism.) My Life A Loaded Gun explores the lives and work of three women poets-Emily Dickinson, Sylvia Plath, and Adrienne Rich-and takes the point of view, now familiar from Gilbert and Gubar, that the critical content of women's art is female rage. Bennett assumes no disjunction between poet and speaker and repeatedly reads the poems as though they provide information about the author. Furthermore, the essence of successful authority seems to be integrity, that unified self so inconceivable to postmodernism. Dickinson, Plath, and Rich all wore "self-alienating masks" during some portion of their lives, claims Bennett, "but all finally learned how to discard the mask and speak directly from the unacceptable core of their beings, to claim their loaded guns." 15

14. See Paula Bennett, My Life A Loaded Gun: Female Creativity and Feminist Poetics (Boston, 1986); Cora Kaplan, Sea Changes: Essays on Culture and Feminism (London, 1986), hereafter abbreviated $S C$; Alicia Suskin Ostriker, Stealing the Language: The Emergence of Women's Poetry in America (Boston, 1986), hereafter abbreviated $S L$; and Jan Montefiore, Feminism and Poetry: Language, Experience, Identity in Women's Writing (London and New York, 1987), hereafter abbreviated FP. For another comparison of Bennett and Ostriker, see my review of these two books in Signs: Journal of Women in Culture and Society 14 (Autumn 1988): 220-22.

15. Bennett, My Life A Loaded Gun, p. 11. 
Bennett is not a stupid critic, and I did find many of her insights fascinating. Furthermore, she does not always ascribe conscious intentions to her poets (she does not make Dickinson a feminist, for instance). She is alert to their inconsistencies and sensitive about the influence of cultural context. However, she does fall into many of the traps exposed by French theory. The author is the meaning of the text, a personal, autobiographical personage who has a "true self" that can be embodied relatively transparently in language. The true self has a singular project: the expression of that "constant, never-changing feminist rage," which Moi says "manages to transform all texts written by women into feminist texts" in American criticism influenced by the Gilbert and Gubar of The Madwoman in the Attic (STP, p. 62).

Ostriker provides another brand of American criticism in Stealing the Language. She is much more savvy about theory than Bennett, a fact made abundantly clear from the beginning of her book where she discusses her own eclectic methodology. Furthermore, Ostriker avoids many of the traps that Bennett falls into by arranging her poems thematically (after the first chapter) rather than reading them in terms of their relation to single authors.

Still, Ostriker wishes to preserve the author as speaker in the text.

A warning is therefore appropriate here for readers who were trained, as I was, not to mistake the " $I$ " in a poem for a real person. The training has its uses, but also its limitations. For most of the poems in this book, academic distinctions between the self and what we in the classroom call the "persona" move to vanishing point. When a woman poet today says " $I$," she is likely to mean herself, as intensely as her verbal skills permit, much as Wordsworth or Keats did, or Blake, or Milton, or John Donne of the Holy Sonnets, before Eliot's "extinction of personality" became the mandatory twentieth-century initiation ritual for young American poets, and before the death of the author became a popular critical fiction. [SL, p. 12]

Ostriker takes the intentions of her poets seriously; the poem may not, and often does not for Ostriker, add up to only what the poet intended. Yet the author is also on stage in the poem. This does not, however, mean-as it does for Bennett's most approved models-that in the best poems women have discarded their masks. Neither does it mean that the best women poets-in a Barthesian mode of playfulness-exploit the freedom of knowing the inevitability of masking. Ostriker says, "When masks and disguises govern the poems, . . . it is not to entertain us but because the mask has grown into the flesh." Furthermore, for Ostriker there is no true self or core of identity to which we can refer the final meaning of a poem. "The split selves in women's poems are both true, both false" (SL, pp. 12, 84). 
However, rather than locating multiplicity as inevitable in all subjective and literary spaces, she implies that this is a special disadvantage of the feminine: "the division reflects and is reinforced by our culture's limited images of feminine personality" (SL, p. 84). For my part, I think it important to accept the notion of all authorial subjectivities as plural while at the same time disentangling the modes of subjectivity available to different groups at different times. For me, the personae that function in the first-person pronouns of John Milton and John Donne must differ from those of William Blake and John Keats, because subjectivity in the seventeenth century meant something different from what it meant in the nineteenth century or means in our own day. Furthermore, I think we still need to explore an individual poem's connections to its cultural setting, its invocation of conventions, and projection of an illusion of self. Though I admire Ostriker's work a great deal, I am perhaps more of a Foucauldian than she.

In what amounts to an attack on male author-centered critics of the mid-twentieth century, Montefiore assigns to romanticism the notion that the author/poet is "a transcendent subject representing the "human spirit," but she finds such romanticism also broadly represented in American women poets like Edna St. Vincent Millay and Adrienne Rich. Millay's conception of the poetic is "that poetry is the articulation of a straightforward subjectivity ('the expression of profoundly felt personal experience')" (FP, p. 124). Criticizing Millay as romantic also means that Montefiore parts company with those feminist critics who have attempted to trace the role of literary expressions in bringing to consciousness conflicts buried in the poet's psyche, critics like Bennett, Ostriker, Gilbert and Gubar, and myself. "To begin with a literary-critical point, the assumption that the significance of a poem is to be identified with the experience and consciousness of the poet is always debatable, because it is the poems which are available to us, not the poet's mind" (FP, p. 5). She refers us to that old chestnut, "The Intentional Fallacy" by W. K. Wimsatt and Monroe C. Beardsley, and also to Barthes's essay, "The Death of the Author."16

Feminism and Poetry is, in fact, an extended argument against author-centered criticism involving a number of points. First, Montefiore says that such criticism often ignores the specific linguistic characteristics of poems. "No other kind of writing holds its own words up to the light as poetry does." Second, she finds such criticism narrow: "criticism based on the assumption that what makes a poem valuable and interesting is its author's awareness, enacted within it, of her own dilemma as a woman (which in practice generally means her sexual/ domestic life) risks reducing everything to the personal" (FP, pp. 6, 5).

16. See W. K. Wimsatt, "The Intentional Fallacy," The Verbal Icon: Studies in the Meaning of Poetry (Lexington, Ky., 1954), pp. 3-18. 
Finally, Montefiore believes that such criticism ignores many problematic aspects of poems, their ambiguity, contradictoriness, openendedness, complicity with patriarchy, though why persons should be less ambiguous, contradictory, or open-ended than poems remains obscure.

But in paying little attention to biographical or historical contexts, since they "would explain some of the causes of the poems, not their textual effects" (FP, p. 134), Montefiore falls into another trap: that of assuming that the poems are "available to us" (that is, are texts) while the cultures and poets themselves remain unavailable (that is, are something other than texts). A critic whose practice is committed to many sets of textual juxtapositions (biographical, cultural, historical) may find Montefiore's work limited in scope and naive about its own formalistic assumptions.

Still, Montefiore, like Margaret Homans whom she admires, is adept at investigating ideological contradictions and linguistic ambiguities. ${ }^{17}$ Her stance gives her a certain lattitude within feminism not shared by others. She can admire a poem (like Sylvia Townsend Warner's "Drawing you, heavy with sleep to draw closer") that does not transcend the assumptions of patriarchy. She can appreciate Dickinson's range of poems, calling them "too ambiguous and contradictory to be read as purely woman-centered texts" ( $F P$, p. 175). Even more interesting, she can relentlessly attack Rich's statements and intentions while clearly (because consistently) preferring her above all contemporary others. In a reading of "Twenty-One Love Poems," Montefiore writes, "Like many of Rich's best poems, this purports to re-create experience straightforwardly, but actually creates a fable" (FP, p. 163). So much for the author's intentions and for the poet's experience as the locus of the poem.

On its own ground, Montefiore's criticism is very shrewd. Where she uses French theory, as she frequently does, to critique essentialist assumptions and the notion of a female space outside history, I find her work quite convincing. However, there are many aspects of the relation between author and text that her critical practice will not illuminate, like the multiple contexts of reading and writing that LaCapra does such a good job of enumerating.

Kaplan, a feminist Marxist critic, comes much closer to my own brand of cultural criticism in her insistence on reading women's work as statements about actual women's experiences in history while not slid-

17. See Margaret Homans, Women Writers and Poetic Identity: Dorothy Wordsworth, Emily Brontë, and Emily Dickinson (Princeton, N.J., 1980), esp. pp. 216-18. Both Homans and Montefiore find the whole question of how women's experience becomes embodied in fictive language so perplexing that they prefer not to discuss any autobiographical traces in women's poems. 
ing over the contradictoriness and opacity of such works as information about the writer's psyche. Kaplan says:

Women's fiction and poetry is a site where women [have] actively structured the meaning of sexual difference in their society, especially and powerfully as it [has] applied to difference between women. . . these writings properly considered undermine the programmatic way in which bourgeois ideology is used as a shorthand by male marxist critics for a unified, genderless, hegemonic system of ideas. [SC, p. 3]

Kaplan constantly interrogates her own political ideologiesMarxist and feminist-illustrating the gaps and contradictions in the ways these ideologies are currently structured. She finds that literature has a lot to say to politics, about the need to reconceptualize Marxism, for instance. Her authors are present and active, intervening in culture though often drawn back into collusion with oppressive cultural practices. ${ }^{18}$

For Kaplan, the engagement of feminism with theory has had considerable effect on critical practice and has been one of the principal factors preventing French structuralist, psychoanalytic, linguistic, and political analysis from being entirely transformed and depoliticized outside of France. However, the usefulness of theory does not mean advocating the death of the author.

Kaplan does not specifically address the idea of the death of the author. Nevertheless, implicit in her analyses is a revised conception of author-function. She applauds Ellen Moers as a critic because "she does not attempt to prove anything about Christina Rossetti's individual experience" (SC, p. 104). Writers have intentions ("these complex lyrics of Rossetti and Dickinson were designed to circumvent the resistance of writer and reader" [ $S C$, p. 114]), but poems are not reducible to intentionality. Indeed, as Anne Sexton (and Elinor Wylie) proclaimed, the writer may not want to know exactly what she is saying in a poem. ${ }^{19}$

Addressing Elizabeth Barrett Browning's Aurora Leigh, Kaplan is perfectly ready to say that the poem memorializes Browning's own

18. The most delightful aspects of Sea Changes for an American reader like me are the way the book embodies energies usefully deployed, the respect it pays to the successful agency of women writers, and the constant sense of Kaplan herself as peripatetic writer, teacher, cultural critic, and political activist. Such work can make one believe that literary criticism and the writing of poetry can be political practices in England, which one is rarely able to believe in the United States.

19. Kaplan quotes Anne Sexton as saying that her poems sometimes had a meaning so deep that she didn't want to know what it was (SC, p. 114). Similarly, Elinor Wylie saw in fictive language a way to avoid "the bitterness of being understood," but also "the bitterness of understanding" (Wylie, "Symbols in Literature," Collected Prose of Elinor Wylie [New York, 1939], pp. 878, 879). 
troubled history, but the point of Kaplan's argument is not to heroinize Browning as much as it is to revise a whole strand of feminist criticism. Kaplan argues that the text suggests that "daughters cannot be constructed wholly as social and psychic victims of their fathers or their fathers as wholly unregenerate villains." Furthermore, "the family romance woven through Aurora Leigh is only one strand of this rich poem" (SC, pp. 211,210$)$.

The essential components of Kaplan's view of authorship are the following: (1) Literary texts have (rather than are) authors. (2) Authors are never full subjective presences because of the fluid nature of subjectivity. (3) Both psychoanalysis and sociopolitical criticism that engages the author's experience in culture can be useful in interpreting texts, though texts are not reducible to such interpretations. (4) One important function of criticism is to see how ideology emerges in the context of a specific historical text or subjectivity, which is simultaneously social and psychic. (5) None of Barthes's so-called hypostases (author, society, history, psyche) are unified or totalizing in their effects, and we can understand more clearly the complexity of culture and psyche by reading literature. A fine summary of Kaplan's position may be found in her presentation of one of the values of fiction.

Literary texts give these simultaneous inscriptions narrative form, pointing towards and opening up the fragmentary nature of social and psychic identity, drawing out the ways in which social meaning is psychically represented. . . . Literary texts tell us more about the intersection of class and gender than we can learn from duly noting the material circumstances and social constraints of characters and authors. [SC, p. 167]

At this point it may seem unnecessary, given my evident admiration for Kaplan's approach to authorship, to proceed any further. However, I have two reasons for wanting to do so. First, since Kaplan does not directly engage "the death of the author," it seems to me worthwhile to formulate the dialogue between postmodernism and feminism emergent from her work. Second, I wish to expand Kaplan's implicit argument for retaining the author-function by adding my own theoretical response to Foucault's question: "What difference does it make who is speaking?"

To return to my introductory summary of post-structuralism's position on the death of the author given in Barthes and Foucault, we might usefully ask: what precisely was killed off in the late $1960 \mathrm{~s}$ when the death of the author was first articulated by French theorists? For Barthes, it was any attempt "to impose a limit on that text, to furnish it 
with a final signified, to close the writing." Pondering a sentence in Balzac, Barthes insists: "No one, no 'person', says it: its source, its voice, is not the true place of the writing, which is reading." But in theory the reader is without attributes: "yet this destination cannot any longer be personal: the reader is without history, biography, psychology; he is simply that someone who holds together in a single field all the traces by which the given text is constituted" ("DA," pp. 147,148).

For Barthes, then, what is killed off with the author is any specific historical subjectivity as a determining factor in textuality. Let us not fall into the trap of misunderstanding his purpose, however. Barthes does not deny that there are authors (he calls them scriptors); he does not insist that real readers have no personalities or historical circumstances. Such assertions would obviously be absurd. What he is claiming is that a proper theory of the text does not make its meaning depend on authors as unified subjectivities or on readers given individual characteristics. Readers make unities out of texts but a text itself is "made up of multiple writings, drawn from many cultures and entering into mutual relations of dialogue, parody, contestation" ("DA," p. 148). In terms of a theory of the text, its unity emerges in readings and can always be reinterpreted.

This is, in fact, far less radical or objectionable than it has been interpreted to be. It simply has the limitations of many theoretical statements. It doesn't address a whole range of issues one may well feel are worth addressing. What it does address is a certain authoritarian critical climate in which "the real meaning" of a text was deciphered either in terms of a unified conception of the author's subjectivity or in terms of a specific kind of reader.

Barthes's essay is short and pithy. Foucault clearly felt it worthwhile the following year to expand on it. To my mind, Foucault's essay is both more and less satisfying than Barthes's. Foucault agrees with Barthes on all the basic issues except that Barthes implies that there is no point in talking about authors at all while Foucault preserves the author-function as characteristic of a historical present in criticism though a critical function in need of interrogation. Though in Foucault, "one has already called back into question the absolute character and founding role of the subject" as author, he goes on to say: "Still, perhaps one must return to this question, not in order to reestablish the theme of an originating subject, but to grasp the subject's points of insertion, modes of functioning, and system of dependencies" ("WIA," p. 118). This will lead to a new set of questions, questions that involve, as we might expect in Foucault, politics and power relations. "What are the modes of existence of this discourse? Where has it been used, how can it circulate, and who can appropriate it for himself? What are the places in it where there is room for possible subjects? Who can assume these various subject functions?" ("WIA," p. 120). 
These are important questions, I would argue, and ones that do not emerge from Barthes's discussion. However, Barthes does not provide hermeneutic guidelines but merely offers a theory about the way writing functions as text. Even Barthes says we can follow up leads in disentangling a text- "the structure can be followed, 'run' (like the thread of a stocking) at every point and at every level, but there is nothing beneath" ("DA," p. 147). Foucault actually says that textuality is political but then seems, in his last words, to deny the significance of politics: "And behind all these questions, we would hear hardly anything but the stirring of an indifference: What difference does it make who is speaking?" ("WIA," p. 120).

Kaplan, in her implicit dialogue with Barthes and Foucault, seems to agree with some points and disagree with others. Authors do not originate texts in the sense that God originates ex nihilo. Still, authors are possible subjectivities whom we may consider as contradictory, fluctuating presences in the text, which she calls significantly a "site." Kaplan is open about her political project as a Marxist critic. She therefore tells us that she is reading not for ultimate meaning but for positional meanings. Feminism and Marxism are alike in fostering such readings.

Kaplan retains all of Foucault's questions about the relevance of author-function to understanding culture. Yet it remains possible in Kaplan's practice to talk about authors as historical agents of cultural criticism and change. The author does exist outside of the writing, has a life (as Browning has a family). It seems to me important to say, as many seem unwilling to do, that this cannot be reconciled with a certain brand of deconstructive criticism that would leave no significant place for authors as functional particularities. ${ }^{20}$

This leads me to my own position on author-function, which I feel supplements Kaplan's in important ways. My problems with Barthes and Foucault certainly do not have to do with the notion that we cannot fix an ultimate meaning through interpretation. Few would dispute that. However, a small point turns into a big point concerning the masculine pronoun used everywhere as representative in their work. Authors and readers are both masculine for Barthes and Foucault.

To Barthes I would want to say, writing is not "the destruction of every voice" but the proliferation of possibilities of hearing. I intend this statement as a feminist reversal of Barthes, as Nelle Morton writes that feminist practice involves "hearing one another to speech." 21 To say this, it seems to me, is a way of calling into question the impersonality of

20. Miller also makes some of these points but seems straining to prevent an open break with French theory. I have tried to be clearer about where I agree and disagree.

21. Nelle Morton, "A Word We Cannot Yet Speak," The Journey Is Home (Boston, 1985), p. 99. See "DA," p. 142. 
Barthes at both the level of his abstract formulations and the level of his linguistic practice, his generic masculine pronouns that obscure the differences among writers and readers.

In Foucault I puzzle over the following statement: "Using all the contrivances that he sets up between himself and what he writes, the writing subject cancels out the signs of his particular individuality. As a result, the mark of the writer is reduced to nothing more than the singularity of his absence; he must assume the role of the dead man in the game of writing" ("WIA," pp. 102-3). Does this work equally well with all writers? Here it seems to me the difference between writing subjectivities is crucial. For H.D., for instance, writing does not place her in the position of the dead man for "she herself is the writing," as she said in one work, and the choice for her is to "write, write or die,"22 not to write and die, as Foucault says is now customary.

Postmodernism has certainly made us aware that we cannot locate full presence anywhere, whether in the psyche, in history, in culture, or in the text. However, presence must be distinguished from what has replaced it. Though there is no presence behind a text, there is an infinite number of presences, or traces, in a given text. One of these presences is the author, about whom we cannot know everything (whose mind is not fully available to us, as Montefiore says). But the text is not present to us outside of interpretation either. There are always questions remaining about any complex text and many "texts" to consider. The success of our intertextual tracings of author in relation to literature will be determined by our readers. Some readers are not interested in the sociological contexts of text construction, but many are, as a recent issue of Critical Inquiry devoted to the sociology of literature attests.

In this issue, Robert Weimann makes a valuable (though somewhat impacted) statement at the beginning of his article, "Text, AuthorFunction, and Appropriation in Modern Narrative: Toward a Sociology of Representation." He says, in effect, that in order to explore the contradictions between textual performance and what might seem to be its determining factors (psyche, history, society, culture), we need a multileveled exploration of textual history, looking "not only on the level of what is represented (which would reduce this project to some genealogy of the signified) but also on the level of who or what is representing." The interdependence of these various levels as well as the disjunction between them is significant to a sociological study of representation. ${ }^{23}$

22. These quotations, widely taken as representative of H.D.'s conception of authorship, are from Helen in Egypt (New York, 1961), p. 22, and Hermetic Definition (New York, 1972), p. 7.

23. See Robert Weimann, "Text, Author-Function, and Appropriation in Modern Narrative: Toward a Sociology of Representation," Critical Inquiry 14 (Spring 1988): 432. 
If it makes sense to ask who or what is representing, under what conditions, with what set of concerns, and so on, it also makes sense to consider how the relation between author and reader differs under different social circumstances. Miller quotes Jonathan Culler on this issue: “For a woman to read as a woman is not to repeat an identity or an experience that is given but to play a role she constructs with reference to her identity as a woman, which is also a construct, so that the series can continue: a woman reading as a woman reading as a woman" ("CS," p. 108). ${ }^{24}$

Third-world women and lesbians have been especially articulate about the importance of reading the work of authors who belong to disenfranchised groups with which they identify. Biddy Martin and Chandra Talpade Mohanty, for instance, raise the issue of author-function in their article "Feminist Politics: What's Home Got to Do with It?" 25 They acknowledge that their experience of reading Minnie Bruce Pratt, the subject of their essay, violates what they call "deconstructive" assumptions about reading and authorship. Pratt's text is conventional in that it collapses the distance between author and narrator, it conveys explicit author intentionality, and it claims personal and political authenticity. Having said this, however, Martin and Mohanty go on to say:

Our reading of Pratt's narrative contends that a so-called conventional narrative such as Pratt's is not only useful but essential in addressing the politically and theoretically urgent questions surrounding identity politics. Just as Pratt refuses the methodological imperative to distinguish between herself as actual biographical referent and her narrator, we have at points allowed ourselves to let our reading of the text speak for us. ${ }^{26}$

A leftist politics, as opposed to a theory, of reading should involve the sense of a legitimate relationship between author and reader as it does, for instance, in essays by Alice Walker, Sherley Anne Williams, Adrienne Rich, and Judy Grahn. ${ }^{27}$ This does not, of course, establish

24. The reference is to Jonathan Culler, On Deconstruction: Theory and Criticism after Structuralism (Ithaca, N.Y., 1982), p. 64.

25. See Biddy Martin and Chandra Talpade Mohanty, "Feminist Politics: What's Home Got to Do with It?" in Feminist Studies / Critical Studies, pp. 191-212.

26. Ibid., p. 194.

27. For examples of impassioned readings, see Alice Walker's In Search of Our Mother's Gardens (San Diego, 1983), and her dedication and afterword to I Love Myself When I Am Laughing . . . And Then Again When I Am Looking Mean and Impressive: A Zora Neale Hurston Reader (Old Westbury, N.Y., 1979); Sherley Anne Williams's foreword to Hurston's Their Eyes Were Watching God (Urbana, Ill., 1978); Adrienne Rich's essay about reading Judy Grahn, "Power and Danger: Works of a Common Woman," On Lies, Secrets, and Silence: Selected Prose 1966-1978 (New York, 1979), pp. 247-58; and Judy Grahn, The Highest Apple: Sappho and the Lesbian Poetic Tradition (San Francisco, 1985), esp. pp. xvi and $x \times i$. 
the author as precisely and uniformly the subjective presence her readers take her to be any more than it establishes the text's meaning as only the one assigned to it by such readers. Though I may not wish to treat texts as the private property of their authors, I am unwilling to lose the sense of vital links between women that only a practice which preserves authors in some form can provide.

My own brand of persona criticism assumes that to erase a woman poet as the author of her poems in favor of an abstract indeterminacy is an act of oppression. However, every version of the persona will be a mask of the author we cannot lightly remove. When one discovers the proliferation of a certain kind of mask in a given poet (the mask of the passionate virgin in Sara Teasdale, for instance), it is interesting to me to ask: What social configurations of the feminine might have led to this mask? Why did so many women readers of the 1920 s delight in it? How representative is this mask and what contradicts it? How can I use my insights about the way masks function in women poets to illuminate previously obscure dimensions of women's history and women's relation to language, authorship, creativity, identity?

We all know that many voices are speaking simultaneously in the poems we read. When I read I am, in a sense, rewriting the poem to suit my own political agenda, but that doesn't necessarily mean that I will construct the poem to duplicate my politics; I may be as likely to hear a patriarchal voice as a feminist one. Or I may feel the poem is interesting precisely because it attempts to evade political analysis.

Ideology will also govern our construction of the author, especially but not only if the author becomes un sujet à aimer, a someone to love. Yes, I want to ask like Foucault "What difference does it make who is speaking?" But I want to answer, the difference it makes, in terms of the voices I can persuade you are speaking, occupies a crucial position in the ongoing discussion of difference itself. 